Dee W. Ford

\title{
Religion and end-of-life decisions in critical care: where the word meets deed
}

Received: 9 March 2012

Accepted: 11 March 2012

Published online: 14 April 2012

(C) Copyright jointly held by Springer and ESICM 2012

This editorial refers to the article available at: doi:10.1007/s00134-012-2554-8.

D. W. Ford ( $)$

Pulmonary and Critical Care Medicine,

Medical University of South Carolina, Charleston, USA

e-mail: fordd@musc.edu

\begin{abstract}
"In his thoughts and his attributes, mankind at large is controlled by inherited beliefs and impulses, which countless thousands of years have ingrained like instinct....in days of illness many millions...still seek their gods rather than the physicians."
\end{abstract}

\section{Sir William Osler [1].}

The 19th and 20th centuries saw a scientific revolution and the establishment of 'modern medicine.' The explosion in medical knowledge, therapies, and technologies is largely attributable to increased focus on the scientific method and empirically demonstrable outcomes. In the 21 st century many clinicians consider the use of evidencebased medicine synonymous with good clinical care. However, as the report from Bülow and colleagues reminds us [2], the human condition is complex and not easily reduced to mere empiric decision-making. This is particularly true in the context of life-altering decisions about end-of-life care or value laden concepts such as patient autonomy, both of which the authors explore [2].

Bülow et al. build on the original ETHICATT study by Sprung and colleagues [3] and add greater granularity to the complex topic of end-of-life decision-making by exploring differences between doctors, nurses, patients, and families self-reporting they are 'religious' as opposed to simply 'affiliated' with a religion. One of the main findings is that, in general, religious individuals favor more aggressive treatment than religion-affiliated individuals. These self-reported preferences are congruent with actual treatments received among patients dying in European intensive care units (ICUs) [4]. These observations may be partially attributable to religious doctrine viewing life as having paramount value, a commonly held view in most religions, yet there is probably greater complexity to the picture. For example, Phelps and colleagues [5] characterized the use of religious-based coping among a cohort of U.S. patients with advanced cancer and found that greater use of religious coping was significantly associated with increased use of ICU therapies prior to death [5]. This was not contingent on a specific religion per se but upon the use of a faith-based psychological coping framework. Our group [6] found that more religious ICU patients and families reported more optimistic perceptions of outcomes of the critical illness, including greater confidence in treatment efficacy. Such optimism regarding favorable ICU outcomes may guide preferences for more aggressive ICU therapies. Finally, being active in a religious community is often associated with social and emotional support during times of illness [7], which may have influences beyond those of individual patients' and families' religious values. Thus, the mechanisms by which religion impacts preferences for and receipt of more aggressive ICU care is likely complicated and merits further investigation.

The importance of religion to many patients and families confronted with end-of-life decisions is irrefutable. Depending on the specific respondent population, anywhere from 53 to $90 \%$ of patients view religion as important in making serious health decisions $[8,9]$, and Bülow et al. [2] found that $60 \%$ of ICU patients and families categorize themselves as religious rather than religion-affiliated. Other reports highlight the importance 
of meeting ICU patients and families religious and spiritual needs. Abbott and colleagues [10] interviewed families of ICU patients 1 year after a decision to withhold or withdraw life-sustaining therapies. Almost half of these families spontaneously reported pastoral care as a fundamental source of psychosocial support. Wall and colleagues [11] found that when a pastor or spiritual advisor was involved in the last $24 \mathrm{~h}$ of an ICU patient's life, there was an independent and positive association with family satisfaction with the overall ICU experience. What is not apparent from existing research is how ICU clinicians should accomplish the goal of supporting patients and families religious and spiritual needs. These findings suggest the importance of building upon others' work [12, 13] to develop and evaluate religious and spiritual interventions in the ICU environment.

There has been less investigation on how doctors' and nurses' religious views influence end-of-life decisionmaking. Sprung et al. [4] found that doctors' religion was significantly associated with withholding and withdrawing ICU therapies and with active shortening of the dying process, and Bülow et al. [2] expand on these findings. Of particular interest are findings that ICU doctors' and nurses' religious persuasions are associated with their opinions about active euthanasia and their perspectives on patient autonomy. Perspectives on active euthanasia are contingent on both religion and region, with religionaffiliated doctors being more likely to support active euthanasia than religious doctors [2]. Significant variation was found in doctors' and nurses' adherence to principles of patient autonomy, which appears to be primarily determined by geographic region rather than religion, with southern European doctors being more likely to act on their medical opinions despite patient preferences to the contrary [2]. However, consideration of the authors' descriptive findings related to ICU professional's religion and patient autonomy is provocative, especially with regards to overriding a competent patient's wishes to forgo life-saving treatments. A majority of Catholics $(53 \%)$ and Jews $(66 \%)$ would override patient preferences in this context, whereas a minority of Protestants would do so $(35 \%)$. This implies meaningful variation between Catholic, Jewish, and Protestant doctors and nurses with regards to boundaries between life, death, and patient autonomy which warrants further exploration [2].

The challenges facing resource-limited healthcare systems that emerge from balancing patient welfare, patient autonomy, and social justice are substantial and will probably only increase given diminishing resources, increasing global cultural heterogeneity, and increasing demand for ICU services throughout much of the developed world. The religious perspectives of patients, families, doctors, and nurses will continue to influence the challenging end-of-life decisions routinely made in ICUs. Thus, a better understanding of the mechanisms by which religion influences end-of-life care, as well as how the religious needs of patients and families can best be supported, is essential. Additionally, ICU professionals should be cognizant of how their own religious views might influence interactions with patients and families and strive towards a balance between personal belief and medical professionalism $[14,15]$.

\section{References}

1. Osler W (1921) Mrs Hepsa Ely Silliman memorial lectures: the evolution of modern medicine. Yale University Press, New Haven

2. Bülow H-H, Sprung C, Baras M, Carmel S, Svantesson M, Benbenishty

J, Maia P, Beishuizen A, Cohen S, Nalos D (2012) Are religion and religiosity important to end-of-life decisions and patient autonomy in the ICU?. The Ethicatt Study. Intensive Care Med. doi:

10.1007/s00134-012-2554-8

3. Sprung C, Carmel S, Sjokvist P, Baras M, Cohen SL, Maia P, Beishuizen A, Nalos D, Novak I, Svantesson M, Benbenishty J, Henderson B, ETHICATT Study Group (2007) Attitudes of European physicians, nurses, patients, and families regarding end-of-life decisions: the ETHICATT study. Intensive Care Med 33:104-110
4. Sprung CL, Maia P, Bulow HH, Ricou B, Armaganidis A, Baras M, Wennberg E, Reinhart K, Cohen SL, Fries DR, Nakos G, Thijs LG (2007) The importance of religious affiliation and culture on end-of-life decisions in European intensive care units. Intensive Care Med 33:1732-1739

5. Phelps AC, Maciejewski PK, Nilsson M, Balboni TA, Wright AA, Paulk ME, Trice E, Schrag D, Peteet JR, Block SD, Prigerson HG (2009) Religious coping and use of intensive life-prolonging care near death in patients with advanced cancer. JAMA 301:1140-1147

6. Ford D, Zapka J, Gebregziabher M, Yang C, Sterba K (2010) Factors associated with illness perception among critically ill patients and surrogates. Chest 138:59-67
7. Koenig HG, Larson DB (2001) Religion and mental health: evidence for an association. Int Rev Psychiatry 13:67-78

8. Koenig HG (1998) Religious attitudes and practices of hospitalized medically ill older adults. Int J Geriat Psychiatry 13:213-224

9. Ehman JW, Ott BB, Short TH, Ciampa RC, Hansen-Flaschen J (1999) Do patients want physicians to inquire about their spiritual or religious beliefs if they become gravely ill? Arch Intern Med 159:1803-1806

10. Abbott KH, Sago JG, Breen CM, Abernethy AP, Tulsky JA (2001) Families looking back: one year after discussion of withdrawal or withholding of life-sustaining support. Crit Care Med 29:197-201

11. Wall RJ, Engelberg RA, Gries CJ, Glavan B, Curtis JR (2007) Spiritual care of families in the intensive care unit. Crit Care Med 35:1084-1090 
12. Lo B, Ruston D, Kates LW, Arnold RM, Cohen CB, Faber-Langendoen K, Pantilat SZ, Puchalski CM, Quill TR, Rabow MW, Schreiber S, Sulmasy DP, Tulsky JA (2002) Discussing religious and spiritual issues at the end of life: a practical guide for physicians. JAMA 287:749-754
13. Puchalski C, Ferrell B, Virani R, OtisGreen S, Baird P, Bull J, Chochinov H, Handzo G, Nelson-Becker H, PrincePaul M, Pugliese K, Sulmasy D (2009) Improving the quality of spiritual care as a dimension of palliative care: the report of the consensus conference. J Palliative Med 12:885-904
14. ABIM Foundation; ACP-ASIM Foundation; European Federation of Internal Medicine (2002) Medical professionalism in the new millennium: a physician charter. Ann Intern Med 136:243-246

15. Medical Professionalism Project (2002) Medical professionalism in the new millennium: physicians' charter. Lancet 359:520-522 